\title{
Cytokine Antibody
}

National Cancer Institute

\section{Source}

National Cancer Institute. Cytokine Antibody. NCI Thesaurus. Code C118490.

Any immunog lobulin that recognizes a cytokine. 